\title{
Level Understanding of Hots Implementation Among Islamic Education Teachers in the Industrial Revolutionary Era 4.0
}

\author{
Muhammad Talhah Ajmain @ Jima'ain ${ }^{1 *}$, Ahmad Zabidi Abdul Razak ${ }^{2}$, Khadijah \\ Abdul Razak ${ }^{3}$, Abdul Basit Samat @ Darawi ${ }^{1}$, Ahmad Marzuki Mohamad ${ }^{1}$ \\ ${ }^{1}$ Faculty Social and Science Humanities, School of Islamic Civilisation Academy, Universiti Teknologi Malaysia \\ (UTM) \\ ${ }^{2}$ Department of Educational Management, Planning and Policy Faculty of Education, Universiti Malaya (UM) \\ ${ }^{3}$ Education Policy \& Leadership, Universiti Kebangsaan Malaysia (UKM) \\ *Corresponding author. Email: mtalhah.uda@gmail.com
}

\begin{abstract}
The era of the Industrial Revolution 4.0 (IR 4.0) demanded that teachers master a wide range of skills. High Order Thinking Skills (HOTS) is an important skill in today's teaching. Teachers' understanding of HOTS will influence the teaching and facilitating ( $\mathrm{PdPc}$ ) of a teacher in building students who can solve their daily problems in the challenging IR 4.0 era. Therefore, this study is conducted on Islamic Education teachers in secondary schools and the purpose of this study is to identify the level of mastery of Islamic Education teachers' understanding of the application of higher order thinking skills (HOTS) in teaching and facilitating $(\mathrm{PdPc})$ Islamic studies. A total of 117 teachers of Islamic Education were involved as respondents in the study. The data obtained were analysed using SPSS Version 22.0 shows that the level of mastery of the teachers in the HOTS is still moderate. The findings of this study, however, indicate that the level of mastery of Islamic Education teachers is high with the score (mean = 4.04). This study would help stakeholders to evaluate their current performance in HOTS which has been in place since 2013, thus improve the quality of teachers in the IR 4.0 era who should have mastered the concept of HOTS.
\end{abstract}

Keywords: Level of Understanding, Islamic Education Teacher, High Order Thinking Skills (HOTS)

\section{INTRODUCTION}

Teacher's skills quality should be aligned with the Industrial Revolution which our world is currently facing. High order thinking skills (HOTS) is required in order to face the global situation and solving the present-day problems. Therefore, it is essential for the teacher's qualities as the executor in order to achieve HOTS Implementation [1], [2], [3] in era IR 4.0 which more towards settlement. The weakness in opposing this IR 4.0, is when the school teachers do not make an effort to understand the concept of HOTS implementation in teaching and facilitation $(\mathrm{PdPc})$. Hence, in this case, it is really important to understand method of teaching HOTS by every teacher.

In general, Trends in International Mathematics and Science Study (TIMSS) and PISA (Programme for International Student Assessment) are assessments in large scale and research projects which shaped to measure the achievement level of students in education internationally [4]. This international TIMSS and PISA research explained that the mastery quality of a teacher is the main factor to determine student's success [5]. However, system's quality cannot exceed teacher's quality [6]. Teachers who had clear understanding on HOTS concept are more likely to make the process of PdPc in IR 4.0 arena which in need of quick solutions, comprehensive and can be practiced. This will provide a more meaningful tutors and effective upon students. In order to produce HOTS students, teachers first need to understand what is HOTS and its concept as well as how to apply it in facing the education of era IR 4.0. Education that hugely relates with daily practices, lifestyles, changes in good behaviour, one of them is Islamic Education field. It is a one great challenge for the Islamic Education teachers to implement HOTS in PdPc which required a clear understanding and skills preparation to utilise HOTS because it involves high cognitive aspect of 
students and how to acquire solutions for daily real life problems of the students that relates to Islamic Education. High order thinking skills (HOTS) is the highest order thinking in the hierarchy of cognitive process. The main element of building HOTS in student is teacher. Therefore, teachers have a huge responsibility and play a big role in order to achieve the Islamic Education goals [7]. Hence, teachers should master the current skills aspect in building student's needs. Level of HOTS understanding upon teachers should get greater exposure regarding IR 4.0 relevance to its challenges, helpful teaching aids and materials which can be obtained from workshops and trainings to improve teacher's quality in teaching and facilitation that can induce impact on students.

Even though, there were researches related to HOTS toward teachers, but there has never been a specific study of HOTS toward Islamic Education teachers in high schools, especially to the point of the level of understanding on implementation skills aspect towards HOTS. Hence, this article is attempting to explain the concepts of HOTS, definitions of challenges for IR 4.0, and the importance of teachers to master the understanding of HOTS.

\section{LITERATURE REVIEW}

The research relating HOTS towards Islamic Education teachers starts to show the difference results, especially in readiness, knowledge and teacher's behaviour toward HOTS. In the aspect of Islamic Education, teacher's understanding on HOTS according to [14] concluded that, the discussions are still about Thinking Skills (KB) which is a skill yet to reach HOTS, and there is a need to refined HOTS Implementation in high schools level, because of the high school's age range are highly potential to observe the student's application with their thinking skills ability.

The misunderstanding on the concept of knowledge for HOTS will happen if the understanding on this matter are not fully mastered [8]. There is research finding, which shows that teachers give multiple definitions relating HOTS [9]. In addition, with the confusions toward the understanding of HOTS concept, teachers are noticed to be more comfortable in using the existing teaching approach and method like giving lectures as well as teacher-centred, whereas the HOTS method is more toward student-centred and varying the activities apart from lectures and lessons form. There are several studies by [10]; [11] \& [12] which shows, HOTS among teachers is still at a low phase, which is parallel to a needs research report by Kestrel Education (UK) and 21 Century Schools (USA) consultant which presented on 2 November 2011 found that high level thinking among teachers in Malaysia are still low, this is because teachers still uses the teaching method of low order thinking skills (LOTS) or teacher-centred.

A more comprehensive research conducted [13] upon 1171 Islamic Education teachers in Malaysia shows that, the understanding of Islamic Education teachers on HOTS skills and its implementation in PdPc is still at the level of LOTS. This is justified by a survey which conducted randomly on 1171 Islamic Education teachers. The results shows less than $62 \%$ from Islamic Education teachers who constantly make practical level discussions, synthesis and assessments. The excuses given by Islamic Education teachers are the understanding of teachers on HOTS is still unclear thus lead to difficulties in assessing and guiding student towards HOTS. In other studies, [3] affirms that, Islamic Education teachers facing the Industrial Revolution 4.0 challenges are not able to relate scientific knowledge with Islamic Education which is relating Allah SWT greatness with elements of science. Even, in the study [14] concluded that, level of teacher's understanding on HOTS in application of IR 4.0 situations are still at a medium level. Thus, Islamic Education teachers should have broader knowledge and clear understanding so that it can be practice in order to relate student's current situation which is facing a sophisticated era and exposed to the challenges of IR 4.0 with the knowledge that could help students to practice Islam in their daily life and solving problems. In conclusion, before implementing teaching of thinking skills, teachers should know and master the thinking skills first [15]. This is because teachers should give guidance for students in mastering those thinking skills [16]. In details, [17] stated that in giving lessons on thinking skills, teachers should know in depth the characteristics of thinking skills which will be taught, know the ways to create a surrounding inside and outside of the classroom that could encourage thinking, and know the methods of assessing thinking skills, because the present knowledge, as well as a clear understanding will shape practicality and precise answers. A research [18], shows that the level of HOTS understanding of Islamic Education teachers in teaching and facilitation process is in medium level. Results from researcher's interview obtained that participants have clear understanding that PdPc process that includes HOTS is a student-centred teaching form where teachers acted as facilitators or helper. Teachers play a role as a guider. This is proven based on researcher's interview [18] with participants, "in presentation, teacher should gude, teacher should also help student who did not finish their homework". Besides that, based on observations done by researchers found that teachers relate the discussions with student's current knowledge and the present reality as how we are stated "imagine you lost someone you love....." and "what will you feel if you experience a disaster....". This clearly shows that teacher's understanding on HOTS application exists, but it is still on a medium level. Moreover, a lack of exposure regarding HOTS also becomes a challenge for teachers. Understanding on HOTS through materials and exercises are hard to be obtained as said "... not so much books on HOTS questions examples, lack of exposure... training for the teachers are not enough." Thus, understanding in this study is to observe how far the Islamic Education teachers were manage to make an attempt to relate knowledge of HOTS on student's current situation during PdPc.

To comprehend, [19] states that in teaching thinking skills, teachers should understand with depth the nature of thinking skills that would be taught, know the ways of creating an environment that can encourage thinking, and know the methods of assessing thinking skills, because the current knowledge as well as a clear a understanding will 
shape practicality and exact answers, as that are the demands in facing challenges of IR 4.0.

\section{METHODOLOGY}

\subsection{Research Scope}

This study uses quantitative methods, where questionnaire as the main instrument. According to [20] and [21], this method is suitable for measuring respondents' views on an issue and achieving the goals towards respondents. Survey are also the best method of data collection in situations where the study population is too large [22]. The sample selection was based on simple random sampling involving Islamic Education teachers teaching in secondary schools in Bangi and Kajang areas. This study took 14 secondary schools as the object of study. Although Selangor is a very large state, Bangi and Kajang areas were chosen due to large population of study areas.

\subsection{Paper Structure}

This study used questionnaires administered by the researcher. The instrument consisted of 10 items measured using a five point likert scale. The items used in this questionnaire were adapted from three thesis studies, [12] [14] [11] which were about the understanding of Islamic Education teachers on the application of HOTS in teaching and facilitating in the IR 4.0 era.

\subsection{Research Location}

The study were administered at 14 Secondary schools in Bangi and Kajang, Selangor. The location of this study was chosen as it was in the area of early exposure in HOTS, accessible to the ministry and also close to educational sources such as Universiti Kebangsaan Malaysia (UKM), Institute of Teacher Studies (IPG), Colleges and others. Additionally, it is close to the researcher's home which is cost effective, easy to reach respondent and responds promptly. So far, studies on high-level thinking skills (HOTS) have yet to be conducted in this area. This has indirectly prompted researchers to conduct studies on mastery of teachers, especially Islamic Education teachers in relation to high school thinking skills.

\subsection{Data Analysis}

Questionnaire were analysed using the Windows SPSS application (Version 22.0). The analysis of this data involves descriptive statistics in order to determine the level of mastery of Islamic Education teachers' understanding the application of HOTS in Islamic Education in IR 4.0. Descriptive statistics are analysis in the form of frequency, percentage and mean to describe the sample of the study and to answer the research questions. According to [23], data analysis using SPSS programming software can produce accurate and error free calculations.

\section{RESEARCH FINDINGS}

\subsection{Respondent Profile Analysis}

The sample distribution of this study include 177 of Islamic Education teachers who teach Islamic Education subject in high schools in the area of Bangi and Kajang, Selangor. The teacher's background analysis is focused on the demographic facts of the respondents. The findings of respondent's profile are shown in Table 1:

Table 1: Respondent's Profile

\begin{tabular}{|c|c|c|c|}
\hline $\begin{array}{l}\text { Demograph } \\
y\end{array}$ & $\begin{array}{l}\text { Respondent } \\
\text { Category }\end{array}$ & $\begin{array}{l}\text { Frequen } \\
\text { cy }\end{array}$ & $\begin{array}{l}\text { Percentage } \\
(\%)\end{array}$ \\
\hline Gender & $\begin{array}{l}\text { Male } \\
\text { Female }\end{array}$ & $\begin{array}{l}12 \\
105 \\
\end{array}$ & $\begin{array}{l}11.4 \% \\
88.6 \%\end{array}$ \\
\hline $\begin{array}{l}\text { Attendance } \\
\text { of HOTS } \\
\text { workshop }\end{array}$ & $\begin{array}{l}\text { Present } \\
\text { Never } \\
\text { present }\end{array}$ & $\begin{array}{l}106 \\
11\end{array}$ & $\begin{array}{l}90.95 \% \\
9.05 \%\end{array}$ \\
\hline
\end{tabular}

Research respondents consist of $12(11.4 \%)$ male teachers and 105 (88.6\%) female teachers. Meanwhile from the aspect of the number of attendees for HOTS workshop, there are more people who attend than the ones who never attend. In general, this studies shows that are more female teachers than male teachers, and the number of attendees are greater than never present. However, the findings are shocking as there are still Islamic Education teachers who never attended the HOTS workshop on the period of HOTS once introduced since the year of 2013.

\subsection{Descriptive Analysis}

The purpose of this section is to answer research questions, which is the level of understanding among Islamic Education teacher's about the application of high order thinking skills (HOTS) in teaching and learning the Islamic Education in order to face the Industrial Revolution 4.0. The analysis results report is shown in form of mean and standard deviation.

\subsection{Mastery of Understanding Level among Islamic Education teachers toward HOTS application}

Based on Table 2, in general, the level of understanding for Islamic Education teachers toward High order thinking skills (HOTS) are at a high level with overall score of mean 3 to 4 as shown on Table 2. However, there are 3 mean item 
with lowest level of understanding where the three are 3.85 and 3.97. Nonetheless, those three items of understanding did not show a distinct difference and it is still at the top level based on mean score.

Table 2: Level of understanding of Islamic Education Teachers Against The Application of High Order Thinking Skills (HOTS) in Facing IR 4.0.

\begin{tabular}{|l|l|l|l|}
\hline No & Item Understanding & Mean & $\begin{array}{l}\text { Std. } \\
\text { Deviation }\end{array}$ \\
\hline 1 & I understand the concept of HOTS applications in the classroom. & 4.07 & .468 \\
\hline 2 & I have an understanding on the aspect of cognitive. & 3.97 & .540 \\
\hline 3 & I understand the aspect of using I-Think in teaching. & 4.09 & .455 \\
\hline 4 & I am able to handle Islamic Education teachings using HOTS. & 4.07 & .504 \\
\hline 5 & I understand the aspect of implementation of thinking skills in solving problems. & 4.09 & .535 \\
\hline 6 & I understand the mode to apply HOTS on every skills aspect of Islamic Education. & 3.97 & .533 \\
\hline 7 & I understand every functions of thinking device that can be used in HOTS. & 3.85 & .567 \\
\hline 8 & I am able to understand HOTS in the workshop that I have attended. & 4.05 & .523 \\
\hline 9 & I believe that HOTS can encourage creativity among students. & 4.21 & .550 \\
\hline 10 & I believe the implementation of HOTS in Islamic Education can produce students who & 4.09 & .689 \\
& are independent. & 4.04 & .379 \\
& Overall & & \\
\hline
\end{tabular}

\section{CONCLUSION \& IMPLICATION, LEVEL OF UNDERSTANDING OF ISLAMIC EDUCATION TEACHERS TOWARD HOTS IMPLEMENTATION IN IR 4.0}

This research shows a very clear picture, how far the level of understanding among Islamic Education teachers in high schools within the area of Selangor towards the implementation of high order thinking skills (HOTS) in teaching and learning Islamic Education. The studies result findings show, level of teachers understanding towards HOTS are at a high level with mean $=4.04$, a small difference with the findings of [14] which shows the level of teacher's understanding towards HOTS in high schools were at a medium level.

Likewise, the study by [18] explains the level of teacher's understanding were at a medium level which conducted in two forms of methods which are quantitative and qualitative with mean $=3.66$. From the findings, results show that, teachers lack the exposure of HOTS. However, in this study, the teacher's understanding is observed well and increasing. Other study conducted in high school [24] expose toward teacher's understanding in Subang and Kota Damansara area about HOTS and the execution among teachers and students are still unclear. However, the study did not represent the subject of Islamic Education. In fact, based on the researcher's view knowing and understanding are two different things, knowing is understanding concept and mastering method and strategy, however understanding HOTS closely related to role, application and results made by teachers in implementing HOTS toward students.
There are some questions asked on this questionnaire that wants to see the teacher's preparations in facing this Industrial Revolution 4.0, among them is the third question "I understand the aspect of using I-Think in teaching". This question is purposely to observe the teaching execution of Islamic Education whether it is suitable with the current world situation. Next, the fifth question which is "I understand the aspect of implementation of thinking skills in solving problems." This is because the challenge and issues in facing IR 4.0 needs for fast and quick solutions, therefore teachers who are worthy to give guidance on the best solution are Islamic Education teachers. And the last one is the tenth question "I believe the implementation of HOTS in Islamic Education can produce students who are independent". This question is important to provide students who are able to be independent outside of their classroom and school which drives them and by how far they have a positive HOTS concept outlooks.

Therefore, we can observe, the higher the understanding of a teacher about HOTS, the easier and more efficient the ways of implementation of HOTS in teaching and learning session take place and it helps to build student's personnel who can face the challenges of IR 4.0. Researcher also observed, a clear understanding of HOTS made teacher able to convey the concept of HOTS to other people. In conclusion, the mastery of Islamic Education teachers toward the understanding of HOTS will make that teacher able to implement skills with confidence and caused HOTS results on students. This again proves that, the understanding toward HOTS knowledge should be taken seriously and it will be explained in practical in HOTS workshops. 


\section{CONCLUSION}

In conclusion, in Industrial Revolution 4.0 (IR 4.0) era demand teachers with multiple skills. High order thinking skills (HOTS) is a crucial skill in every teaching nowadays. The teacher's understanding toward HOTS will effect teaching and facilitation (PdPc) of that teacher in building a student who is able to solve every day's problem in challenging IR 4.0. Therefore, this research is one of the study which conducted among Islamic Education teachers in high schools where the purpose is to recognize the level of understanding Islamic Education teachers towards the implementation of high order thinking skills (HOTS) in teaching and facilitation $(\mathrm{PdPc})$ of Islamic Education. Result from this study shows the level of understanding among Islamic Education teachers are at a high level. Questions asked are related to the preparations of Islamic Education teachers in facing the IR 4.0. Hopefully this research can help those who are involved to evaluate HOTS current performance which started since the year of 2013, which then helps to grow teacher's quality in era IR 4.0 where the understanding concept of HOTS should be mastered well.

\section{REFERENCES}

[1] King, FJ., Goodson,L., \& Rohani, F., Higher Order Thinking Skill. Source: www.cala.fsu.edu, 1998.

[2] Marlina Sabran, Kemahiran Berfikir Aras Tinggi (KBAT) Pelajar Tingkatan 5 Dalam Penyelesaian Masalah Matematik. Tesis Srjana Muda. Universiti Kebangsaan Malaysia, 2013.

[3] Fahimah Ali Hassan, Faza Ali Hassan, Hilmi Ali Hassan \& Aderi Che Noh, Cabaran Guru Pendidikan slam dalam Melaksanakan Inovasi dan Perubahan Pendidikan slam Sekolah Rendah, 2014. www.ukm.my/wpi10/files/jadual-pembentangan09122014.pdf. [2 Februari 2020]

[4] Mullis, . V. S., Martin, M. O., \& Foy, P. (with Olson, J. F., Preuschoff, C., Erberber, E., Arora, A., \& Galia, J.). (2008). TIMSS 2007 International mathematics report: Findings from EA's Trends in International Mathematics and Science Study at the fourth and eighth grades. Chestnut Hill, MA: TIMSS \& PIRLS nternational Study Center, Boston College.

[5] Salihuddin Suhadi, Baharuddin Aris, Hasnah Mohammed, Norasykin Zaid \& Zaleha Abdullah, Penguasaan Pelajar Dalam Kemahiran Berfikir Aras Tinggi Dengan Pembelajaran Kaedah Sokratik. Konvensyen Antarabangsa Jiwa Pendidik, 2014, pp. 1113.
[6] Maszuria A. Ghani, Salina Omar, Marina Abdul Majid \& Rosnah A. Rajak, Guru dan Cabaran Semasa. Kuala Lumpur. Freemind Horizons. Sdn. Bhd, 2014.

[7] Al-Kaylani, Majid Arsan, Ahdaf Altarbiyyah AlIslamiyyah. Dubai: Dar al-Qalam, Emiriah Arab Bersatu, 2005.

[8] Talhah Ajmain \& Aderi Che Noh, Kefahaman Ilmu Dan Kemahiran Berfikir Aras Tinggi Mampu Melahirkan Pelajar Yang Mengajar. Prosoding, Wacana pendidikan Islam siri ke-11, 2016.

[9] Amir Khan, Aderi Che Noh \& Tarmimi Hussein, Amalan Kemahiran Berfikir Aras Tinggi Dalam Pengajaran Pendidikan Islam. Prosiding, Wacana pendidikan Islam siri ke-11, 2016.

[10] Rajendran Nagappan, The Teaching of Higher Order Thinking Skill in Malaysia. Journal of Southeast Asian Education, 2(1), 2001.

[11] Nurliyana Abd Halim, Pengetahuan, Sikap dan Kesediaan Pelajar Tehadap Kemahiran Berfikir Aras Tinggi dalam Pembelajaran Pemahaman Bacaan. Tesis. UKM, 2015.

[12] Ahmad Tarmizi, Kualiti Guru Pendidikan slam Sekolah Menengah di Daerah Seberang Prai Utara Pulau Pinang. Tesis Sarjana. UKM, 2016.

[13] Ainol Madziah, Aspek Penilaian dan Pentaksiran Bagi KBAT \& Kemahiran nsaniah. Seminar, Muzakarah Pakar: Pembentangan Kajian Keberkesanan Pendidikan slam. IKIM, 2015

[14] Hasmaliza Hasan, Persepsi Guru Bahasa Melayu Sekolah Menengah Kebangsaan Terhadap Penerapan Kemahiran Berfikir Aras Tinggi dalam Pengajaran dan Pembelajaran. Tesis Sarjana. UKM, 2016.

[15] Beyer, B. K., Critical Thinking. Indiana: Phi Delta Kappa Educational Foundation, 1995.

[16] Som \& Dahalan Ramli, Kemahiran Berfikir Secara Kritis dan Kreatif (KBKK). Selangor. Pearson Malaysia Sdn Bhd, 1998.

[17] Phillips, J.A., Pengajaran Kemahiran Berfikir: Teori dan Amalan. Kuala Lumpur: Utusan Publications \& Distributors Sdn. Bhd, 1997.

[18] Norasmahani Nor, Sofiah Suhaimi, Syamira Abdul Wahab, Khushairi Che Ismail, Aderi Che Noh, Khadijah Abdul Razak, Pelaksanaan KBAT dalam Pengajaran dan Pembelajaran Pendidikan Islam Sekolah Menengah: Satu Tinjauan di Putrajaya, Proceeding: 7th 
International Seminar on Regional Education, November 5-7, 2015, 361- 375.

[19] Hanani Hussin, Aderi Che Noh, \& Ab. Halim Tamuri, The Religious Practices Teaching Pedagogy of Islamic Education Excellent Teachers. Mediterranean Journal of Social Sciences, 5(16) (2014) 239-246. http://doi.org/10.5901/mjss.2014.v5n16p239.

[20] Syed Arabi Idid, Kaedah Penyelidikan Komunikasi Dan Sains Sosial. Kuala Lumpur: Dewan Bahasa dan Pustaka, 1998.

[21] Najib Ghafar, Penyelidikan Pendidikan. Skudai: Penerbitan Universiti Teknologi Malaysia, 2003.

[22] Babbie, E., The Practice of Social Research (9th ed.). Belmont: Wadsworth Publishing Company, 2004.

[23] Majid K., Kaedah Penyelidikan Pendidikan. Kuala Lumpur: Dewan Bahasa dan Pustaka, 2009.

[24] Vijayaletcmy Muniyandy \& Selvam Narayanasamy, Persepsi Guru-Guru Terhadap Martabat Keguruan Dalam Milenium Baru: Berlaku Peningkatan atau Kemerosotan?. Proceeding 6th Pedagogy International Seminar, 1, (2015) 203-220. SBN 978979-3786-50-6. 